\title{
PERAN SERTA MASYARAKAT DALAM PENGELOLAAN SAMPAH SEBAGAI KUNCI KEBERHASILAN DALAM MENGELOLA SAMPAH
}

\author{
Ni Made Armadi ${ }^{1}$ Program Doktor Studi Ilmu Lingkungan, Universitas Udayana, \\ adearmadi@rocketmail.com
}

Vol. 35 No. 1 (2021): p 9-24

Submitted: March 28 $8^{\text {nd }}, 2021$ Accepted: May 12 ${ }^{\text {th }}, 2021$

\begin{tabular}{l}
\hline Keywords: \\
Community Role; \\
Waste; 3R \\
\hline
\end{tabular}

\begin{tabular}{lc}
\hline Kata & kunci: \\
Sampah; & Peran \\
Masyarakat; $3 R$ \\
\hline
\end{tabular}

\section{PENDAHULUAN}

Permasalahan sampah merupakan masalah yang harus dihadapi oleh masyarakat, dan menjadi isu lokal, regional, nasional bahkan international, sejalan dengan meningkatnya jumlah penduduk, kemajuan teknologi, dan gaya hidup, sehingga berdampak terhadap meningkatnya jumlah dan jenis timbulan sampah yang

\begin{abstract} community. It is the forefront of waste management. The purpose of this study was to determine the role of the community in waste management as the key to successfully managing waste. The research method used was literature study and interviews. The result of this research was that the community participation in Denpasar City was quite effective in waste management activities through composting and $3 R$ (reuse, reduce and recycle). Denpasar Government provided incentives for integrated waste management as a stimulus to improve community's active involvement.

\begin{tabular}{l} 
Abstrak \\
\hline Permasalahan sampah merupakan masalah yang harus \\
dihadapi masyarakat dan telah menjadi masalah global. \\
Masyarakat merupakan ujung tombak dalam pengelolaan \\
sampah. Tujuan dari penelitian ini adalah untuk mengetahui \\
peran serta masyarakat dalam pengelolaan sampah sebagai \\
kunci keberhasilan dalam mengelola sampah. Metode \\
penelitian yang digunakan yakni studi literatur dan \\
wawancara. Hasil penelitian ini adalah peran serta \\
masyarakat di Kota Denpasar cukup efektif dalam kegiatan \\
pengelolaan sampah melalui pengomposan dan 3R (reuse, \\
reduce and recycle). Pemerintah Kota Denpasar memberikan \\
insentif dalam pengelolaan sampah terpadu sebagai \\
rangsangan untuk meningkatkan semangat masyarakat. \\
\hline
\end{tabular}
\end{abstract}


semakin beragam di setiap daerah. Sampah merupakan salah satu wujud pencemaran lingkungan dimana sampah dapat menimbulkan dampak terhadap kesehatan masyarakat, seperti; bau, banjir, merusak estetika, kebakaran, efek rumah kaca dan lain sebagainya. Permasalahan sampah hingga saat ini belum ada cara yang tepat untuk mengatasinya, sehingga perlu dilakukan secara komprehensif dan terpadu dari hulu sampai ke hilir agar dapat memberi manfaat bagi pemerintah dan masyarakat pada umumnya, baik dari segi ekonomi, sosial, budaya dan produk yang dihasilkan merupakan teknologi ramah lingkungan.

Aktivitas manusia pada umumnya menghasilkan sampah, dimana jumlah atau volume sampah sebanding dengan tingkat konsumsi masyarakat terhadap barang/material yang digunakan sehari-hari. Demikian juga dengan jenis sampah, sangat tergantung dari jenis material yang dikonsumsi oleh masyarakat (Nurkomalasari, 2014). Pengelolaan sampah rumah tangga memerlukan partisipasi aktif masyarakat agar peran pemerintah tidak semakin berat. Meningkatkan partisipasi masyarakat dalam pengelolaan sampah dapat dicapai jika para orang tua atau orang dewasa melakukan pengelolaan sampah di rumah tangga dalam kehidupan seharihari, yaitu dengan memisahkan sampah organik dengan sampah non organik. Dengan ini diharapkan anak-anak meniru perilaku pengelolaan sampah yang dilakukan orang tua atau dewasa. Perilaku yang ditanamkan semenjak dini tersebut akan menjadi sebuah kebiassan yang sangat mendukung peningkatan partisipasi masyarakat.

Partisipasi masyarakat dalam pengelolaan sampah merupakan bentuk keterlibatan dan keikutsertaan masyarakat secara aktif dan sukarela dalam keseluruhan proses pengelolaan sampah. Perilaku sehat diharapkan dapat memelihara, meningkatkan kesehatan dan melindungi diri dari ancaman penyakit, sedangkan lingkungan sehat diharapkan dapat menciptakan lingkungan yang kondusif, bebas polusi, pemukiman yang sehat dan pengelolaan sampah yang sehat (Azkha, 2016). Pengelolaan sampah rumah tangga dengan melibatkan partisipasi masyarakat dapat mereduksi timbulan sampah yang di buang ke Tempat Pemrosesan Akhir (TPA) sampah (Artiningsih, 2008).

Pertumbuhan penduduk yang semakin meningkat dan berubahnya pola konsumsi masyarakat menyebabkan bertambahnya volume, jenis dan karakteristik sampah. Laju produksi sampah terus meningkat, tidak saja sejalan dengan laju 
pertumbuhan penduduk tetapi juga sejalan dengan meningkatnya pola konsumsi masyarakat, dan tingkat pendapatan masyarakat (pendapatan tinggi, pendapatan menengah dan pendapatan rendah) pada umumnya (Riswan dan Hadiyarto, 2011). Permasalahan sampah mutlak harus ditangani secara bersama-sama dengan melibatkan semua stakeholder yaitu antara pemerintah, lembaga swadaya masyarakat, perguruan tinggi dan masyarakat itu sendiri. Oleh karena itu dibutuhkan kesadaran dan komitmen bersama untuk perubahan sikap, perilaku dan etika yang berbudaya dan ramah lingkungan, (Artiningsih, 2008). Dalam upaya penanganan permasalahan sampah untuk menciptakan kualitas lingkungan yang bersih dan hijau serta ramah lingkungan maka harus dilakukan perubahan paradigma pengelolaan sampah dengan cara pengurangan volume sampah dari sumbernya dengan melaksanakan pengurangan sampah melalui gerakan 3R (Reduse, Reuse dan Recycle) dengan keterlibatan langsung oleh masyarakat. (KLHK, 2012).

Strategi penerapan 3R dalam pengelolaan sampah di tingkat masyarakat salah satunya adalah pembentukan bank sampah, dimana bank sampah pada prinsipnya adalah satu rekayasa sosial/ kegiatan masyarakat dari masyarakat oleh masyarakat dan untuk masyarakat dalam memilah sampah. Pelaksanaan bank sampah dapat memberikan output nyata bagi masyarakat berupa kesempatan kerja dalam melaksanakan manajemen operasi bank sampah dan investasi dalam bentuk tabungan, sehingga masyarakat mendapatkan income dari bekerja di bank sampah. Pengelolaan sampah rumah tangga berbasis masyarakat dengan kegiatan 3R, bertujuan untuk melatih kemandirian masyarakat dalam mempertahankan kebersihan lingkungan, dengan prinsip partisipasi masyarakat, kemandirian, efesiensi, perlindungan lingkungan, serta keterpaduan (Riswan dan Hadiyarto, 2011).

Pengelolaan sampah diperlukan kepastian hukum, kejelasan tanggung jawab dan kewenangan pemerintah, pemerintah daerah serta peran serta masyarakat dan dunia usaha sehingga pengelolaan sampah dapat berjalan secara proporsional, efektif dan efisien. Saat ini sebagian besar masyarakat masih memandang sampah sebagai barang sisa yang tidak berguna, bukan sebagai sumber daya yang perlu untuk dimanfaatkan. Masyarakat dalam pengelolaan sampah masih bertumpu pada pendekatan akhir (end-of-pipe), yaitu sampah dikumpulkan, diangkut dan dibuang ke tempat pemrosesan akhir sampah. Padahal timbunan sampah dengan volume yang 
besar di lokasi tempat pemrosesan akhir sampah berpotensi melepas gas metan $\left(\mathrm{CH}_{4}\right)$ yang dapat meningkatkan emisi gas rumah kaca dan memberikan kontribusi terhadap pemanasan global.

Provinsi Bali saat ini sudah mempunyai Peraturan Gubernur Nomor 95 Tahun 2018 tentang Kebijakan dan Straegi Daerah (Jakstrada) dalam Pengeloaan Sampah Rumah Tangga dan Sampah Sejenis Sampah Rumah Tangga, dimana dalam peraturan tersebut arahnya mencakup, peningkatan kinerja pengurangan sampah rumah tangga dan sampah sejenis rumah tangga, dan peningkatan kinerja penanganan sampah rumah tangga dan sampah sejenis sampah rumah tangga. Bersamaan dengan peraturan tersebut dikeluarkan juga Peraturan Gubernur Bali Nomor 97 tahun 2018 tentang Pembatasan timbulan Sampah Plastik Sekali Pakai, serta Peraturan Gubernur Bali Nomor 47 Tahun 2019. Peraturan tersebut merupakan terobosan baru dalam pengelolaan sampah yang melibatkan seluruh pemangku kepentingan untuk mengelola sampah secara terintegrasi mulai dari sumber sampah sampai ke pemrosesan akhir sampah.

Peraturan Gubernur Bali Nomor 47 Tahun 2019 tentang Pengelolaan Sampah Berbasis Sumber bertujuan untuk mempercepat dalam upaya melindungi dan memperbaiki alam serta lingkungan Bali, khususnya dalam bidang pengelolaan sampah rumah tangga, atau sampah sejenis sampah rumah tangga. Seiring dengan hal tersebut Pemerintah Kota Denpasar juga mengeluarkan Peraturan Walikota No. 36 Tahun 2018 tentang Pengurangan Kantong Plastik dalam rangka mewujudkan Kota Denpasar yang berwawasan budaya khususnya budaya bersih secara berkesinambungan. Beberapa regulasi yang mengatur tentang pengelolaan sampah sampai saat ini Pemerintah belum bisa menyelesaikan dan mengatasi sepenuhnya persoalan masalah sampah.

Sistem pengelolaan sampah rumah tangga di Kota Denpasar, mempunyai sistem pengelolaan sampah yang hampir sama dengan kota-kota besar lainnya yaitu masih tergolong menggunakan model tradisional yang menganut pola kumpul, angkut, buang ke TPA (end off pipe), dimana seakan-akan persoalan sampah dapat diselesaikan dengan membangun TPA saja, meskipun demikian sistem pengolahan sampah secara mandiri sebagian kecil sudah dilakukan di Kota Denpasar, dengan 
prinsip 3R, yaitu mengurangi (Reduce) menggunakan kembali (Reuse) dan mendaur ulang sampah (Recycle).

Sistem yang berjalan di wilayah Kota Denpasar belum terlihat optimal dalam meningkatkan pengelolaan sampahnya demikian juga partisipasi masyarakatnya dalam pengelolaan sampah masih kurang. Pengelolaan sampah di Kota Denpasar dalam hal ini bisa dilihat bahwa belum mampu menekan laju timbulan sampah sehingga menyebabkan volume sampah terus mengalami peningkatan yang tajam baik di TPS maupun di TPA, (Masterplan Kota Denpasar, 2017)

Sistem pengelolaan sampah dengan partisipasi masyarakat yang diharapkan di Kota Denpasar, merupakan strategi mitigasi pengelolaan sampah dalam penurunan emisi Gas Rumah Kaca karena tingginya timbulan sampah di TPA merupakan salah satu faktor yang berkontribusi terhadap tingginya emisi gas rumah kaca, serta hal ini menjadi penting juga untuk dibuatkan model pengelolaan sampah yang cocok dan adaptif di Kota Denpasar untuk menyelesaikan permasalahan pengelolaan sampah (Mitchell, Bruce, Setiawan, B, Rahmi, 2015). Berdasarkan latar belakang dan penelitian sebelumnya terkait pengelolaan sampah maka penelitian ini memiliki tujuan yakni untuk mengetahui peran serta masyarakat dalam pengelolaan sampah rumah tangga sebagai kunci keberhasilan dalam mengelola sampah.

\section{METODE PENELITIAN}

Penelitian ini dirancang dengan metode kaulitatif terlabih dahulu dengan melihat beberapa aspek yang berkaitan dengan penelitian, dengan melihat gambaran tentang kondisi pengelolaan sampah rumah tangga di Kota Denpasar serta survei responden terkait prilaku masyarakat dalam mengelola sampah dan wawancara dengan sejumlah pakar persampahan. Penelitian ini berlokasi di Wilayah Kota Denpasar, yang tersebar di 4 (empat) kecamatan yang ada di Kota Denpasar yaitu Kecamatan Denpasar Utara, Denpasar Timur, Kecamata Denpasar Selatan dan Kecamatan Denpasar Barat. Wawancara terhadap tokoh, para pakar dan pelaku pengelolaan sampah dilaksanakan pada bulan Juli-September Tahun 2020. 


\section{HASIL PENELITIAN DAN PEMBAHASAN}

Peran masyarakat dalam pengelolaan sampah di Kota Denpasar merupakan ujung tombak dari aspek pengelolaan sampah yang dilakukan oleh masyarakat, termasuk yang dilaksanakan oleh Desa Adat di masing-masing Kecamatan. Kesadaran masyarakat dan PMJK untuk sub sektor persampahan di Kota Denpasar dapat dilihat pada Tabel 1 Pengelolaan Persampahan di Tingkat Kelurahan/Kecamatan, Tabel 2 Pengelolaan Persampahan di Tingkat Kota Denpasar dan Tabel 3 Daftar Program/Proyek Layanan Yang Berbasis Masyarakat.

Tabel 1 Pengelolaan Persampahan di Tingkat Kelurahan/Kecamatan di Kota Denpasar

\begin{tabular}{|c|c|c|c|c|c|c|}
\hline \multirow[t]{2}{*}{ Jenis kegiatan } & \multicolumn{2}{|c|}{$\begin{array}{c}\text { Dikelola oleh } \\
\text { Masyarakat } \\
\text { Banjar }\end{array}$} & \multicolumn{2}{|c|}{$\begin{array}{c}\text { Dikelola oleh Sektor Formal } \\
\text { ditingkat Kelurahan/Kecamatan }\end{array}$} & \multicolumn{2}{|c|}{$\begin{array}{c}\text { Dikelola } \\
\text { Pihak } \\
\text { Swasta }\end{array}$} \\
\hline & L & $\mathbf{P}$ & L & $\mathbf{P}$ & L & $\mathbf{P}$ \\
\hline $\begin{array}{l}\text { Pengumpulan } \\
\text { sampah dari rumah }\end{array}$ & $\sqrt{ }$ & $\sqrt{ }$ & $\sqrt{ }$ & $\sqrt{ }$ & $\sqrt{ }$ & $\sqrt{ }$ \\
\hline $\begin{array}{l}\text { Pemilahan sampah } \\
\text { di TPS }\end{array}$ & $\sqrt{ }$ & $\sqrt{ }$ & $\sqrt{ }$ & $\sqrt{ }$ & $\sqrt{ }$ & $\sqrt{ }$ \\
\hline $\begin{array}{l}\text { Pengangkutan } \\
\text { Sampah ke TPS }\end{array}$ & $\sqrt{ }$ & $\sqrt{ }$ & $\sqrt{ }$ & $\sqrt{ }$ & $\sqrt{ }$ & $\sqrt{ }$ \\
\hline $\begin{array}{l}\text { Pengangkutan } \\
\text { sampah ke TPA }\end{array}$ & $\sqrt{ }$ & - & $\sqrt{ }$ & - & $\sqrt{ }$ & - \\
\hline $\begin{array}{l}\text { Pemilahan sampah } \\
\text { di TPA }\end{array}$ & $\sqrt{ }$ & $\sqrt{ }$ & $\sqrt{ }$ & $\sqrt{ }$ & $\sqrt{ }$ & $\sqrt{ }$ \\
\hline Para Penyapu Jalan & $\sqrt{ }$ & $\sqrt{ }$ & $\sqrt{ }$ & $\sqrt{ }$ & $\sqrt{ }$ & $\sqrt{ }$ \\
\hline
\end{tabular}

Sumber: DLHK Kota Denpasar, 2017

Tabel 2 Pengelolaan Persampahan di Tingkat Kota Denpasar

\begin{tabular}{|c|c|c|c|c|c|c|c|c|}
\hline \multirow[t]{2}{*}{ Jenis Kegiatan } & \multicolumn{2}{|c|}{$\begin{array}{c}\text { Dikelola oleh } \\
\text { Kabupaten/Kota }\end{array}$} & \multicolumn{2}{|c|}{$\begin{array}{c}\text { Dikelola oleh } \\
\text { Masyarakat }\end{array}$} & \multicolumn{2}{|c|}{$\begin{array}{l}\text { Dikelola oleh } \\
\text { Sektor Formal }\end{array}$} & \multicolumn{2}{|c|}{$\begin{array}{c}\text { Dikelola } \\
\text { Pihak } \\
\text { Swasta }\end{array}$} \\
\hline & $\mathbf{L}$ & $\mathbf{P}$ & L & $\mathbf{P}$ & $\mathbf{L}$ & $\mathbf{P}$ & $\mathbf{L}$ & $\mathbf{P}$ \\
\hline $\begin{array}{l}\text { Pengumpulan } \\
\text { sampah dari rumah }\end{array}$ & $\sqrt{ }$ & $\sqrt{ }$ & $\sqrt{ }$ & $\sqrt{ }$ & $\sqrt{ }$ & $\sqrt{ }$ & $\sqrt{ }$ & $\sqrt{ }$ \\
\hline $\begin{array}{l}\text { Pemilahan sampah } \\
\text { di TPS }\end{array}$ & $\sqrt{ }$ & $\sqrt{ }$ & $\sqrt{ }$ & $\sqrt{ }$ & $\sqrt{ }$ & $\sqrt{ }$ & $\sqrt{ }$ & $\sqrt{ }$ \\
\hline $\begin{array}{l}\text { Pengangkutan } \\
\text { Sampah ke TPS }\end{array}$ & $\sqrt{ }$ & $\sqrt{ }$ & $\sqrt{ }$ & $\sqrt{ }$ & $\sqrt{ }$ & $\sqrt{ }$ & $\sqrt{ }$ & $\sqrt{ }$ \\
\hline $\begin{array}{l}\text { Pengangkutan } \\
\text { sampah ke TPA }\end{array}$ & $\sqrt{ }$ & - & $\sqrt{ }$ & - & $\sqrt{ }$ & - & $\sqrt{ }$ & - \\
\hline $\begin{array}{l}\text { Pemilahan sampah } \\
\text { di TPA }\end{array}$ & $\sqrt{ }$ & $\sqrt{ }$ & $\sqrt{ }$ & $\sqrt{ }$ & $\sqrt{ }$ & $\sqrt{ }$ & $\sqrt{ }$ & $\sqrt{ }$ \\
\hline
\end{tabular}


Para Penyapu Jalan $\sqrt{ }$

$\sqrt{ } \quad \sqrt{ }$

Sumber: DLHK Kota Denpasar, 2017

Tabel 3 Daftar Program/Proyek Layanan Yang Berbasis Masyarakat

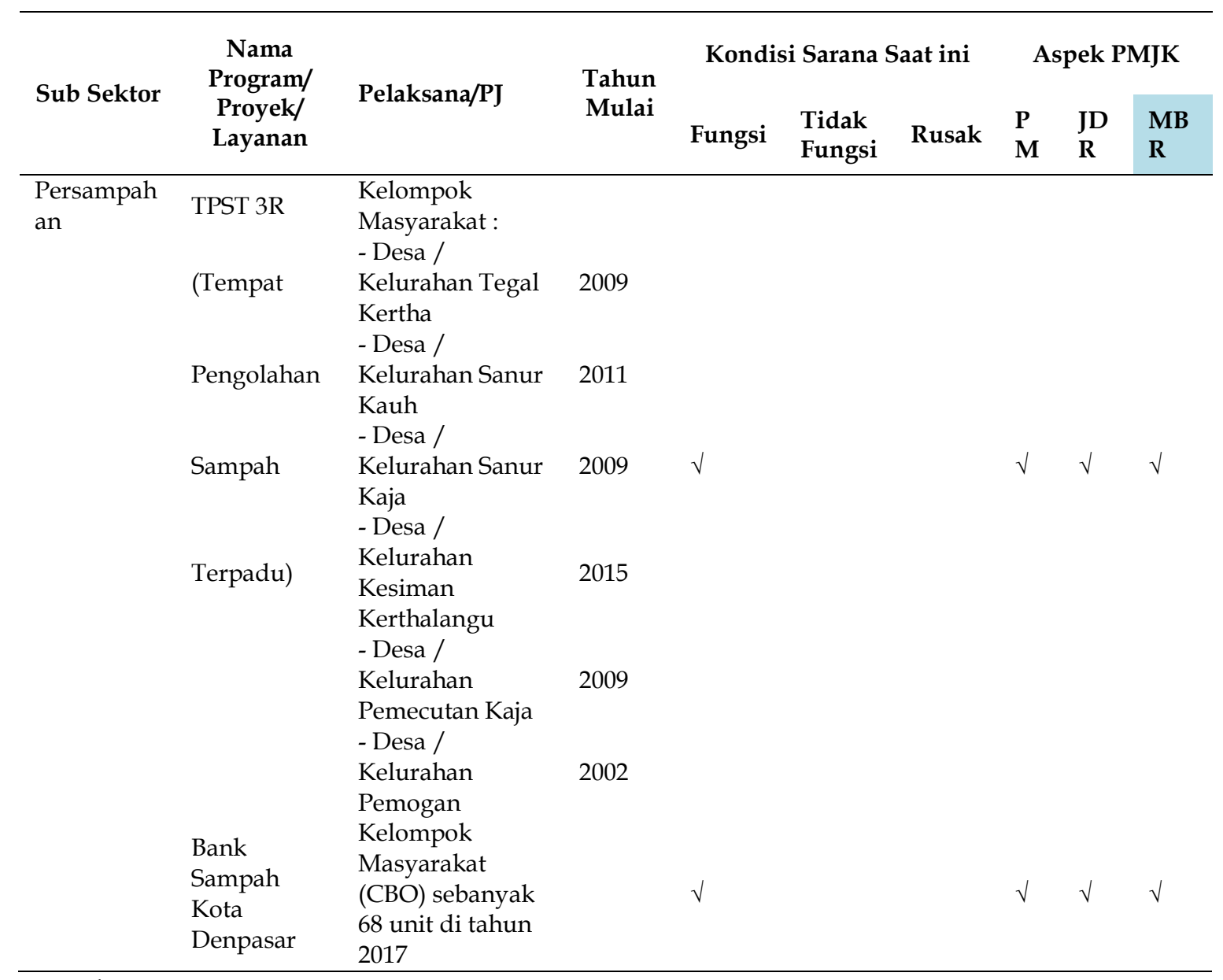

Sumber: DLHK Kota Denpasar, 2017

Kebijakan-kebijakan yang memberikan peluang terhadap penanggulangan sampah di Kota Denpasar ini antara lain komitmen pemerintah dalam penanggulangan sampah, adanya investor yang berminat dalam pengelolaan sampah, dan adanya sumbangan pemikiran dari berbagai instansi dan lembaga swadaya masyarakat. Namun demikian ancaman dalam upaya penanggulangan sampah ini terutama disebabkan karena rendahnya kesadaran masyarakat, meningkatnya konsumsi masyarakat, adanya pergeseran gaya hidup masyarakat yang serba menggunakan plastik dan cenderung menggunakan barang-barang sekali pakai sebagai pengaruh dari budaya Barat, dan adanya sampah kiriman dari wilayah sekitar. 
Selain itu, untuk penanggulangan sampah diperlukan pembagian peran yang jelas begitu juga peraturannya.

Permasalahan dalam penganggulangan sampah di Kota Denpasar dapat dijelaskan, yakni belum memadainya sarana dan prasana pengelolaan sampah, sehingga belum semua wilayah dapat terlayani. Penerapan Retribusi dan peraturan belum memadai. Masih rendahnya tingkat kesadaran masyarakat dalam mematuhi peraturan dalam bidang kebersihan. Teknologi pengelolaan persampahan masih sederhana. Sosialisasi kelembagaan pengelola persampahan yang bersifat regional (SARBAGITA) dan pembagian peran masing-masing daerah belum memadai. Kualitas sarana dan prasarana pendukung TPA masih dibawah standar. Program pendukung untuk advokasi, penyadaran dan penguatan kapasitas masyarakat untuk sektor persampahan masih minim. Adanya pergeseran gaya hidup masyarakat yang serba menggunakan plastik dan cenderung menggunakan barang-barang sekali pakai

Pengelolaan persampahan merupakan tanggung jawab semua pihak, baik pemerintah daerah, sektor bisnis, sektor pendidikan, dan masyarakat luas. Selama ini masyarakat sudah ikut serta dalam pengelolaan sampah antara lain dengan cara membuang sampah ke tempat penampungan sementara, menimbun sampah di pekarangan sendiri dan membakar sampah

Peran serta masyarakat dalam bidang persampahan adalah keterlibatan masyarakat dalam bertanggung jawab pasif maupun aktif, secara individu, keluarga, kelompok dan masyarakat untuk mewujudkan kebersihan bagi diri sendiri dan lingkungan. Peran masyarakat dalam mengurangi gas rumah kaca masih belum optimal. Masyarakat sebaiknya meningkatkan peran dalam mengurangi sampah di sumber untuk mengurangi gas rumah kaca, dengan melakukan penyadaran bersama seperti melakukan pengolahan sampah melalui pengomposan dan TPST 3R. Membakar sampah harus dikurangi untuk menghindari pembntukan gas rumah kaca.

Sungguh merupakan hal yang sangat baik bila peran serta masyarakat memenuhi syarat untuk menjadi sub sistem, tetapi kondisi masyarakat tidak dapat dipaksakan karena menyangkut masalah sosial budaya dan homogenitas, sehingga hanya daerah tertentu saja yang mampu untuk melaksanakannya. Hal tersebut bukannya peran serta masyarakat tidak dapat diharapkan, tetapi memerlukan waktu untuk mengkondisikannya, sehingga pada tahap (setting) pertama peran serta 
masyarakat dianggap sebagai komponen lingkungan. Peran serta masyarakat tersebut dapat dilaksanakan melalui beberapa cara dan tahapan, yang pertama sejauh ini kelompok kerja yang telah dibuat tidak berjalan dengan maksimal. Untuk itu perlu dilakukan penguatan kapasitas dengan meningkatkan kapabilitas kelompok kerja yang terdiri dari berbagai stakeholder, diantaranya anggota masyarakat, pemulung, LSM, Desa Adat, komunitas peduli sampah, bank sampah, kelompok pemuda, Dinas Kebersihan, Swasta, Lembaga pendidikan dan Badan Perencanaan Pembangunan Kota Denpasar yang disatukan dalam sebuah forum. Masing-masing kelompok kerja mempunyai tanggung jawab untuk mengidentifikasi/mengumpulkan permasalahan yang dihadapi terkait dengan pengelolaan sampah. Dari berbagai kelompok kerja tersebut terdapat satu orang ketua forum yang akan menjembatani berbagai permasalahan dan usulan penanganan yang akan dan dapat dilaksanakan agar pengelolaan sampah sesuai dengan target yang diharapkan. Kondisi saat ini banyak masyarakat dan stake holder lainnya yang menaruh perhatian pada masalah sampah namun karena belum adanya program kerja / target yang jelas maka hasil yang dicapai masih jauh dari memuaskan. Kedua, pemberian pengetahuan pentingnya pengelolaan sampah sejak dini mulai dari TK hingga sekolah lanjutan atas dengan memberikan pengetahuan tentang sampah dan lingkungan dan meningkatkan kepedulian mereka tentang kebersihan melalui praktek pengelolaan sampah skala kecil. Pentingnya kesadaran akan pengelolaan sampah perlu ditanamkan sejak dini pada anak-anak. Ketiga, kerjasama dengan berbagai perguruan tinggi dalam rangka pengembangan pengelolaan sampah melalui penyusunan blue print pengelolaan sampah, penelitian tentang sampah, perencanaan pengelolaan sampah berkelanjutan dan teknologi tepat guna dalam pengelolaan sampah. Tersedianya infrastruktur yang mendukung pengelolaan sampah, misalnya kondisi jalan yang layak, tersedianya tempat khusus yang secara resmi berfungsi untuk mendaur ulang sampah, keterlibatan pemulung dalam upaya mengurangi sampah sangat besar. Semakin banyaknya pemulung saat ini maka diperlukan adanya organisasi yang dapat mengkoordinir dan membina pemulung-pemulung agar hasil kerja mereka lebih optimal serta pembinaan dalam hal keselamatan kerja.

Pembentukan forum kelompok kerja yang terdiri dari berbagai stakeholder, diantaranya anggota masyarakat, pemulung, LSM, Dinas Kebersihan, Swasta, 
Lembaga pendidikan dan Badan Perencanaan Pembangunan Kota Denpasar. Masingmasing kelompok kerja mempunyai tanggung jawab untuk mengidentifikasi/mengumpulkan permasalahan yang dihadapi terkait dengan pengelolaan sampah. Dari berbagai kelompok kerja tersebut terdapat satu orang ketua forum yang akan menjembatani berbagai permasalahan dan usulan penanganan yang akan dan dapat dilaksanakan agar pengelolaan sampah sesuai dengan target yang diharapkan.

Peningkatan laju produksi sampah disebabkan karena adanya pertumbuhan penduduk dan kenaikan tingkat konsumsi masyarakat. Dengan dilakukan pembinaan, sosialisasi dan penerapan aturan dengan ketat, kesadaran masyarakat dalam pengelolaan sampah berangsur meningkat. Pendekatan lainnya yang dilakukan oleh Pemerintah Kota Denpasar adalah mengembangkan sistem pengelolaan sampah sedekat mungkin dengan sumber sampah agar pengurangan, penanganan, dan penegakan hukum terhadap pengelolaan sampah dapat berjalan dengan efektif melalui satuan terkecil dari masyarakat melalui memberdayakan peran masyarakat mulai dari tingkat rumah tangga melalui pemilahan sampah organik dan anorganik, pelibatan kelompok komunal masyarakat seperti banjar, desa adat, bank sampah dan kelompok lainnya yang mempunyai komitmen kuat dalam pengelolaan sampah berbasis masyarakat dapat berjalan pada satuan terkecil masyarakat secara desentralisasi agar pengelolaan sampah dapat dilakukan secara mandiri di masyarakat. Pelibatan desa adat dalam pengelolaan sampah dikemukakan oleh Kepala Dinas Lingkungan Hidup Kota Denpasar dalam wawancara yang dilakukan pada 4 Agustus 2020 sebagai berikut :

“...............Pengelolaan sampah berbasis masyarakat atau lingkungan dilakukan di Kota Denpasar dengan melibatkan desa adat dengan membentuk kelompok swakelola, karena desa adat di Kota Denpasar sudah memiliki awig-awig dan pararem. Peran masyarakat dalam pengelolaan sampah diatur dalam Peraturan Daerah Kota Denpasar No. 1 tentang ketertiban umum dan Peraturan Daerah Kota Denpasar No. 3 tentang Pengelolaan Sampah. Mayarakat ikut bersama-sama mengelola sampah mulai dari sumber sampah dan sangsi yang diterapkan tindak pidana ringan dan denda 50 juta, tetapi tindakan yang terpenting adalah penyadaran. Peran serta masyarakat mulai nampak melalui pengelolaan sampah berbasis partisipasi masyarakat, berbasis sekolah dan berbasis sumber atau pengelolaan mulai dari rumah tangga, dimana sampah organik diolah menjadi kompos dan sampah anorganik dibawa ke Bank Sampah. Disisi lain pengelolaan sampah organik melalui sistem biopori yang dibangun di masing-masing rumah tangga dan membentuk kelompok swakelola sampah di banjar- 
banjar diatur melalui Peraturan Walikota Denpasar No. 76 Tahun 2019, dimana sistem pengelolaan dapat melalui desa adat atau melalui Bumdes. Moci boleh membawa sampah ke TPST atau TPS sedangkan pengangkutan sampah dengan mobil dibawa langsung ke TPA. Penanganan sampah di Kota Denpasar juga menggandeng komunitas setiap kegiatan kerja bakti, gotong royong dan menggandeng pihak swasta melalui CSR, ibu PKK dan seke teruna teruni. Sumber anggaran pengelolaan sampah di Kota Denpasar berasal dari dana pusat, APBD, CSR dan dana yang bersumber dari swadaya masyarakat. Untuk kelembagaan pengelolaan sampah, Kota Denpasar ditangani oleh Dinas Lingkungan Hidup dan membentuk Unit Pelayanan Terpadu Pengelolaan Sampah dengan tupoksi menangani Bank Sampah dan 3R. Di sumber kesadaran masyarakat masih kurang, sambil pelan-pelan dilibatkan desa adat. Inovasi pengelolaan sampah berupa Underground, Sidarling, Pesan Gadis".

Sistem pengelolaan sampah di Kota Denpasar sudah cukup komprehensif mulai dari hulu sampai ke hilir atau mulai dari sistem yang dibentuk oleh Pemerintah Kota Denpasar dengan membuat regulasi sebagai pijakan pelaksanaan pengelolaan sampah sampai melibatkan unsur swasta, kominitas, desa adat, seke teruna-teruni dan rumah tangga dalam pengelolaan sampah. Bebagai inovasi yang telah dikembangkan seperti tempat pembuangan sampah (TPS) underground atau tempat pembuangan sampah bawah tanah tengah dikembangkan di Kota Denpasar. TPS model ini dinilai tepat untuk mengatasi luberan sampah berbau menyengat. Dinas Lingkungan Hidup dan Kebersihan (DLHK) Kota Denpasar, telah memasang TPS bawah tanah di tiga tempat yaitu TPS paling besar ada di Jalan Pulau Kawe, kemudian ukuran kecil berkapasitas dua kubik ada di Lapangan Puputan I Gusti Ngurah Made Agung sebanyak dua buah dan satu lagi di Taman Kota Lumintang dan menambahkan pemasangan TPS Underground di tempat umum lainnya. Terlebih pada kantor-kantor yang ada di lingkungan Pemerintahan Kota Denpasar. 


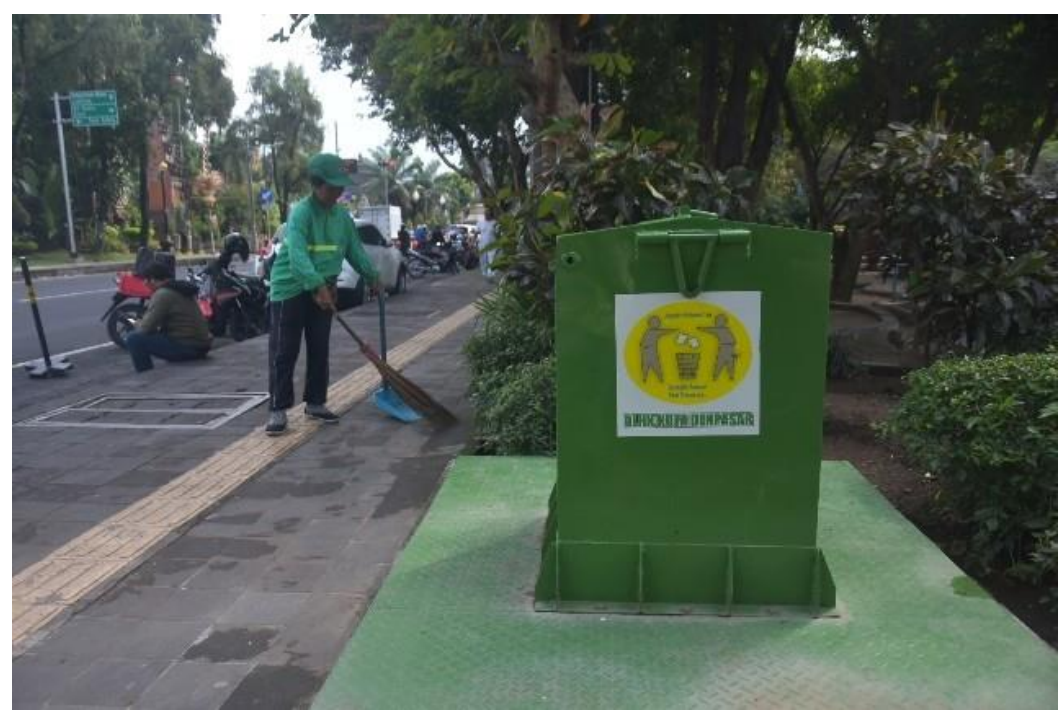

Gambar 1. TPS Underground

Inovasi lainnya adalah Sistem Informasi Sadar dan Peduli Lingkungan (Sidarling). Sistem reward di Sidarling berdasarkan jumlah poin yakni silvar dengan pengumpulan poin 0-24 akan mendapatkan layanan bus sekolah gratis; gold dengan pengumpulan poin 25-75 dengan layanan yang didapatkan yaitu bus sekolah gratis, diskon belanja di beberapa toko, prioritas pelayanan (KK,KTP, perizinan, BD, pembayaran air/listrik), pelayanan rumah sakit dan puskesmas; dan platinum dengan pengumpulan 75 poin ke atas dengan layanan yang diperoleh bus sekolah gratis, diskon belanja di beberapa toko, prioritas pelayanan (KK, KTP, perizinan, BPD, pembayaran air/listrik), pelayanan rumah sakit dan puskesmas, serta beasiswa bagi siswa sekolah. Pemerintah Kota Denpasar dalam kebijakan dan strategi pengelolaan sampah serta penanganannya telah melakukan beberapa terobosan atau inovasi. Antara lain, penetapan Peraturan Walikota Denpasar Nomor 36 tahun 2018 tentang Pengurangan Penggunaan Kantong Plastik.

Inovasi berikutnya adalah inovasi Pesan Gadis. Untuk meningkatkan upaya penanganan sampah di Kota Denpasar dan mengurangi peredaran sampah yang dibuang sembarangan ke lingkungan, serta mengoptimalkan pelayanan kepada masyarakat dalam pengelolaan persampahan maka Pemerintah Kota Denpasar melalui Dinas Lingkungan Hidup dan Kebersihan melaksanakan inovasi Layanan Pengangkutan Sampah Besar Gratis di Kota Denpasar (Pesan Gadis) di Kota Denpasar. 
Pertumbuhan Kota Denpasar di samping telah menghasilkan kemajuankemajuan dalam berbagai bidang penghidupan dan kehidupan perkotaan juga telah menimbulkan masalah pembangunan dan perkembangan perkotaan yang tidak kecil. Salah satunya yaitu timbulnya permasalahan lingkungan seperti terjadinya pencemaran dan meningkatnya volume sampah. Ditambah lagi dengan pola konsumsi masyarakat perkotaan yang cenderung konsumtif sehingga mengakibatkan tingginya volume sampah yang dihasilkan. Hal tersebut tentu mengindikasikan pentingnya upaya pengelolaan sampah di Kota Denpasar. Upaya pengelolaan sampah sesuai dengan UU No. 18 tahun 2008, didefinisikan sebagai kegiatan yang sistematis, menyeluruh, dan berkesinambungan yang meliputi pengurangan dan penanganan sampah.

Sesuai dengan Perpres No. 97 Tahun 2017 tentang Kebijakan dan Strategi Nasional Pengelolaan Sampah Rumah Tangga dan Sampah Sejenis Sampah Rumah Tangga (Jakstranas), diamanatkan bahwa pengelolaan sampah dilakukan melalui pengurangan sampah dan penanganan sampah. Untuk upaya pengurangan sampah ditargetkan hingga 30\% sedangkan upaya penanganan sampah ditargetkan sebesar $70 \%$ pada tahun 2025. Untuk mendukung target pencapaian tersebut dan mengingat Kota Denpasar sebagai Kota yang terus melakukan pembangunan di segala bidang, maka Pemerintah Kota Denpasar melalui Dinas Lingkungan Hidup dan Kebersihan Kota Denpasar terus berupaya meningkatkan upaya pengelolaan sampah, baik melalui sosialisasi kebijakan pengelolaan persampahan, upaya 3R (reduce, reuse, recycle), pembentukan bank sampah, dan komposting, sampai penyusunan peraturan terkait dengan pengelolaan persampahan, termasuk penerbitan Peraturan Walikota No. 36 Tahun 2018 tentang Pengurangan Penggunaan Kantong Plastik dan Instruksi Walikota Denpasar No. 1 Tahun 2018 tentang Pengurangan Sampah. Dalam upaya penanganan sampah, Pemerintah Kota Denpasar juga telah berupaya melakukan upaya pemilahan, pengumpulan, pengangkutan, pengolahan sampah melalui komposting, dan pelayanan kebersihan di ruas-ruas jalan. Berbagai sarana dan prasarana pengelolaan persampahan juga terus ditingkatkan. Namun, pada kenyataan masih saja terdapat sampah yang tercecer yang dengan sengaja dibuang oleh oknum masyarakat di tempat-tempat terbuka, tanah kosong, tegalan, saluran drainase, dan sungai. Bahkan, 
jenis sampah yang dibuang termasuk juga sampah besar seperti kasur rusak, bantal bekas, lemari rusak, kulkas rusak, dan sebagainya.

Pengelolaan sampah dari hulu juga didorong oleh dasar hukum dengan menerbitkan Peraturan Daerah Kota Denpasar Nomor 3 Tahun 2015 tentang Pengelolaan Sampah, dimana dalam pengelolaan sampah memberikan peran kepada desa adat dalam mengelola sampah secara mandiri dan bisa melibatkan pihak lain dalam pengelolaan sampah. Pada hakekatnya pengelolaan sampah bernasisi masyarakat melalui pemberdayaan desa adat dan masyarakat telah dilakukan di Kota Denpasar .mulai dari hulu atau dari sumber sampah rumah tangga hingga sampah yang masuk ke TPA berkurang.

Berdasarkan data dari DLHK Kota Denpasar bahwa sumber sampah Kota Denpasar sebagian besar atau 90\% bersumber dari sampah rumah tangga dengan komposisi 70\% sampah organik dan 30\% sampah anorganik. Inovasi berikutnya yang dilakukan oleh Kota Denpasar adalah Sistem Pengelolaan Sampah Secara Mandiri Berbasis Masyarakat dengan menerapkan paradigma baru pengelolaan sampah yang berkelanjutan dengan prinsip 3R (Reduce, Reuse, dan Recycle) yang pada intinya memandang sampah sebagai sumber daya yang mempunyai nilai ekonomis dan dapat dimanfaatkan untuk energi, diolah menjadi kompos, pupuk dan bahan baku industri berbasis swakelola. Sistem Pengelolaan Sampah Secara Mandiri Berbasis Masyarakat bertujuan untuk mengajak masyarakat memanfaatkan sampah agar menjadi barang yang ekonomis sehingga sampah bisa berkurang. Sampah-sampah organik yang sudah tidak bisa digunakan sebagai kerajinan akan di bawa ke TPST dan didaur ulang menjadi kompos. Sampah anorganik masih banyak yang bisa digunakan sebagai kerajinan dan menghasilkan uang, tidak hanya dengan itu pengurangan sampah juga dilakukan dengan menanamkan sejak dini ke anak-anak untuk membawa bekal dari rumah agar mengurangi sampah plastik. Kedua, Penanganan Sampah, Dalam Undang-Undang Nomor 18 Tahun 2008 tentang Pengelolaan Sampah, terdapat 5 cara atau metode yang digunakan untuk melakukan penanganan sampah berwawasan lingkungan yaitu pemilihan, pengumpulan, pengangkutan, pengolahan dan pemrosesan akhir. Memilah sampah sesuai dengan jenisnya sangat penting, sebab itu membantu untuk efektivitas pengelolaan sampah. Memilah harus di ajarkan sejak dini agar di jiwa 
anak-anak sudah tertanam kebiasaan yang sedemikian rupa, selain memilah pengumpulan juga perlu karena pengumpulan sampah di TPST terdekat sangat berpengaruh pada timbunan sampah yang ada di TPA. Setelah pengumpulan, sampah-sampah akan diangkut oleh pengangkutan dari dinas DLHK maupun swaloka yang berjenis truk atau motor bak roda tiga, pengangkutan sampah biasanya dilakukan setiap hari ke tiap-tiap rumah tangga. Pihak Dinas juga akan memberikan sanksi bagi warga yang membuang sampah sembarangan, sanksi sosialnya berupa membersihkan lingkungan disekitar ia membuang sampah sembarangan atau pun membersihkan kantor DLHK, sedangkan untuk sanksi beratnya akan dikenakan denda sebesar 50 juta atau kurungan yang sesuai dengan kesalahan. Sistem yang sudah dibuat tersebut seperti peraturan daerah, peraturan walikota perlu dilakukan monitoring dan ketegasan dalam pelaksanaannya, seperti wawancara yang dilakukan dengan salah satu kelihan adat Bapak Widiada pada tanggal 3 Agustus 2020 sebagai berikut :

“........... Pengelolaan sampah di Kota Denpasar adalah mengurangi sampah dari sumbernya. Pemerintah Kota Denpasar sudah mengeluarkan peraturan daerah, peraturan walikota yang didalamnya memuat sangsi, permasalahannya adalah sangsinya kurang tegas, apabila ada yang membuang sampah di telajakan di trotoar atau membuang sampah pada waktu yang telah ditentukan. Sebaiknya penerapannya ada kerjasama dengan masyarakat dan tokoh masyarakat, jika terjadi pelanggaran kemana jalurnya apakah ditipiring. Sekarang tinggal penerapan aturan dan sangsi. Pemilahan sampah yang masih kurang dan kembali lagi penerapan aturan dan sangsi supaya tidak menjadi macam kertas. Kalau membuat kompos ada untuk mendukung kegiatan masyarakat dan penanganan sampah yang tidak bisa didaur ulang sudah berjalan. Masyarakat mulai sadar di setiap banjar dan kelurahan dalam swakelola penanganan sampah seperti pada pengangkutan sampah, sedangkan untuk pengolahan sampah sudah berjalan 30\%".

Partisipasi masyarakat dalam pengelolaan sampah perlu ditingkatkan terutama pada aspek pemilahan sampah. Semakin sadar dan meningkat masyarakat yang melakukan pemilahan mulai dari tingkat rumah tangga akan semakin baik. Pengolahan sampah secara swakelola penting dilakukan untuk menekan jumlah sampah yang dibawa ke TPA. Sebaiknya sampah diselesaikan terlebih dahulu di tingkat rumah tangga, bank sampah dan komunitas, kemudian sisa sampah yang tidak dikelola habis di tingkat rumah tangga, bank sampah dan komunitas baru dibawa ke TPA seperti yang terungkap pada hasil wawancara dengan Ibu Ria Pengelola Bank Sampah pada tanggal 29 Juni 2020. 
“........... Yang seharusnya ditekankan adalah pengelolaan sampah berbasis sumber, tetapi yang dimaksud sebagai swakelola sampah adalah jasa angkut sampah, ini kan fatal, sama saja kemudian DLHP yang mengangkut sampah dari jalan yang dibawa ke TPA. Jadilah sampah itu diangkut ke TPS kemudian ke TPA sehingga tidak ada pengurangan sampah. Perlu penekanan pada penanganan sampah secara swakelola yang aspeknya adalah pemilahan, pengolahan dan aspek 3R. sebaiknya sampah sebelum dibuang dipilah dulu di tingkat rumah tangga. Semakin banyak yang memilah semakin meningkat partisipasi masyarakat. Sampah sangat sulit bekerja sama dengan pengepul, karena mereka spesifik menerima jenis sampah. Kalau kita bank sampah tidak mempunyai mobil sendiri tidak bisa jalan. Berdasarkan aturan kita bank sampah harus mengurangi sampah. Yang terjadi di masyarakat kemana sampah anorganik dibawa padahal banyak bank sampah. Perlu bantuan yang dibutuhkan adalah mesin press dan listrik agar bank sampah bisa jalan".

\section{KESIMPULAN}

Peran serta masyarakat di Kota Denpasar cukup efektif dalam kegiatan pengelolaan sampah melalui pengomposan dan $3 \mathrm{R}$ (reuse, reduce and recycle). Peran masyarakat dalam mengurangi gas rumah kaca perlu ditingkatkan lagi dengan membangun unit percontohan pengomposan atau 3R di tiap banjar, desa adat dan kelurahan. Pemerintah Kota Denpasar memberikan insentif dalam pengelolaan sampah terpadu sebagai rangsangan untuk meningkatkan semangat masyarakat.

\section{DAFTAR PUSTAKA}

Artiningsih, N. komang A. (2008). Peran Serta Masyarakat dalam Pengelolaan Sampah Rumah Tangga (Studi kasus di Sampangan dan Jomblang, Kota Semarang).

Azkha, N. (2016). Analisis Timbulan, Komposisi dan Karakteristik Sampah di Kota Padang. Jurnal Kesehatan Masyarakat, 1(1).

Mitchell, Bruce, Setiawan, B, Rahmi, D. H. (2015). Pengelolaan Sumber Daya Lingkungan. Yogyakarta: Gadjah Mada University Press.

Nurkomalasari, D. (2014). Pengembangan Model pengelolaan Sampah Rumah Tangga Berbasis Masyarakat di RW 08 Merbabu Asih Kota Cirebon. Journal of Educational Social Studies, 3(2).

Peraturan Gubernur Bali Nomor 95 Tahun 2018

Peraturan Gubernur Bali Nomor 97 tahun 2018

Peraturan Gubernur Bali Nomor 47 Tahun 2019

Peraturan Walikota Denpasar No. 36 Tahun 2018

Peraturan Walikota Denpasar No. 76 Tahun 2019

Riswan, Henna Rya Sunoko dan Hadiyarto, A. (2011). Pengelolaan Sampah Rumah Tangga di Kecamatan Daha Selatan. Jurnal Ilmu Lingkungan, 9(1). 